\title{
ST
}

Science \& Technology

PAPER - OPEN ACCESS

\section{Pengaruh Motivasi dan Jenis Bahan Ajar Terhadap Hasil Belajar Kimia Siswa}

$\begin{array}{ll}\text { Author } & : \text { Manasse Hasugian dkk., } \\ \text { DOI } & : 10.32734 / \text { st.v2i1.342 } \\ \text { Electronic ISSN } & : 2654-7082 \\ \text { Print ISSN } & : 2654-7074\end{array}$

Volume 2 Issue 1-2018 TALENTA Conference Series: Science \& Technology (ST)

This work is licensed under a Creative Commons Attribution-NoDerivatives 4.0 International License.

Published under licence by TALENTA Publisher, Universitas Sumatera Utara

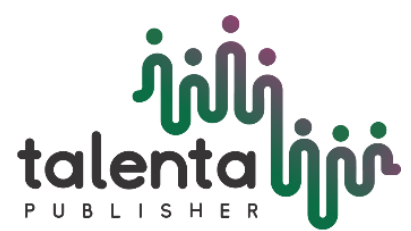




\title{
نं \\ TM Conference Series 02 (2019) talentalioi

\section{Pengaruh Motivasi dan Jenis Bahan Ajar Terhadap Hasil Belajar Kimia Siswa}

\author{
Manasse Hasugian* \\ Program Study Kimia, Pascasarjana, Universitas Sumatera Medan, Medan
}

\begin{abstract}
Tujuan penelitian ini adalah untuk mengetahui apakah ada interaksi antara motivasi dan bahan ajar terhadap hasil belajar siswa pada pokok bahasan Hidrolisis Garam di SMA Negeri 15 Medan. Dalam penelitian ini dibandingkan pengaruh antara motivasi dengan jenis bahan ajar terhadap hasil belajar kimia siswa. Subjek dalam penelitan ini adalah siswa kelas XI IPA SMA Negeri 15 Medan sebanyak 48 orang yang dibagi dalam 4 kelompok berdasarkan tingkat homogenitasnya. Tingkat homogenitas siswa ditentukan dari hasil pretest siswa,buku pegangan siswa, keikutsertaan dalam les belajar dan tingkat motivasi yang hampir sama. Dalam penelitian ini ada dua faktor yang diteliti yaitu faktor motivasi (A) dan faktor bahan ajar (B). Untuk faktor motivasi ada 2 taraf yaitu motivasi tinggi dan motivasi rendah, sedangkan faktor bahan ajar ada dua taraf yaitu modul dan buku teks siswa. Hasil penelitian menunjukan ada interaksi antara motivasi belajar siswa dengan jenis bahan ajar terhadap rataan nilai hasil belajar kimia siswa. Pengujian sederhana dari faktor motivasi untuk taraf B1 ( bahan ajar modul) didapat hasil bahwa rataan nilai hasil belajar kimia siswa yang menggunakan bahan ajar modul dengan motivasi tinggi) tidak berbeda nyata dengan hasil belajar siswa yang menggunakan bahan ajar modul dengan motivasi rendah. Pada pengujian sederhana faktor motivasi untuk taraf B2 (bahan ajar buku paket) didapat hasil bahwa rataan nilai hasil belajar kimia siswa yang menggunakan bahan ajar buku paket dengan motivasi tinggi berbeda nyata dengan hasil belajar siswa yang menggunakan bahan ajar buku paket dengan motivasi rendah. Dengan demikian disimpulkan bahwa terdapat perbedaan nilai hasil belajar siswa yang diajar dengan bahan ajar modul dan buku paket yag dikombinasikan dengan tingkat motivasi tinggi dan motivasi rendah. Diperoleh bahwa siswa yang motivasi tinggi lebih cocok menggunakan bahan ajar buku paket, siswa yag motivasi rendah lebih cocok diajar dengan menggunakan modul.
\end{abstract}

Kata Kunci : motivasi, bahan ajar, hasil belajar, kimia

\section{Pendahuluan}

Kimia merupakan ilmu yang sarat dengan konsep mulai dari konsep yang sederhana sampai dengan konsep yang lebih kompleks. Bagi sebagian siswa pelajaran kimia merupakan pelajaran yang sulit dipahami. Keterlibatan siswa dalam kegiatan belajarmengajar sangat kecil. Ini yang menyebabkan siswa enggan berpikir, sehinggatimbul perasaan jenuh dan bosan dalam mengikuti pelajaran kimia. Kurangnya strategi dan bahan ajar yang diberikan guru membuat siswa kurang termotivasi untuk belajar. Keberhasilan pembelajaran kimia pada jenjang pendidikan SekolahMenengah Umum (SMU) menjadi harapan semua pihak khususnya guru kimia. Menurut Sabri [1], guru merupakan pemegang peranan utama dalam proses belajar mengajar. Dalam proses belajar mengajar perlu melibatkan berbagai macam kegiatanyang harus dilakukan, terutama jika menginginkan hasil yang optimal. Salah satucara yang dapat dipakai agar mendapatkan hasil optimal seperti yang diinginkanadalah memberi tekanan dalam proses pembelajaran. Hal ini dapat dilaksanakandengan memilih salah satu bahan ajar yang tepat.

Menurut Manik [2] dinyatakan bahwa hasil belajar siswa yang diajar dengan menggunakan bahan ajar modul lebih tinggi dibandingkan dengan hasil belajar siswa yang diajar dengan menggunakan handout dan terjadi peningkatan hasil belajar sebesar 61,26\%. Pasaribu [3] mengemukakan bahwa efektivitas penggunaan bahan ajar modul adalah 
62,39\%.Selanjutnya Sinaga [4] mengemukakan bahwa pembelajaran dengan menggunakan buku paket kurang meningkatkan hasil belajar daripada menggunaan handout.

Faktor lain yangsangat menentukan hasil belajar siswa adalah motivasi. Berdasarkan penelitian Setyowati [5], besarnya motivasi belajar yang mempengaruhi hasil belajar siswa kelas VII SMPN 13 Semarang ini sebesar 29, 766\% sedangkan 71,344\% dipengaruhi olehfaktor-faktor lain. Siswa dengan motivasi belajar tinggi, prestasinya akan lebih baikdibandingkan dengan siswa dengan motivasi rendah.Sering dijumpai siswa yang memiliki intelegensi yang tinggi tetapi prestasi belajar yang dicapainya rendah, akibat kemampuan intelektual yang dimilikinya kurang berfungsi secara optimal. Salah satu faktor pendukung agar kemampuan intelektual yang dimiliki siswa dapat berfungsi optimal adalah adanya motivasi untuk berprestasi tinggi dalam dirinya.

Walaupun penelitian tentang model pembelajaran dan motivasi belajar telah banyak dilakukan peneliti, namun sejauh ini belum ada penelitian yang mengkombinasikan antara bahan ajar dengan motivasi belajar siswa. Dengan demikian berdasarkan uraian di atas peneliti mengangkat masalah ini ke dalam skripsi dengan judul :" Pengaruh Motivasi dan Jenis Bahan Ajar Terhadap Hasil Belajar Kimia Siswa”.

\section{Metode Penelitian}

\subsection{Populasi dan Sampel Penelitan.}

Populasi dalam penelitian ini adalah semua siswa kelas XI SMA Negeri 15 Medan Tahun Ajaran 2010/2011 sebanyak 8 kelas. Sampel diambil dengan dua tahap yaitu sampel kelas diambil secara acak sebanyak 2 kelas, kemudian diambil sampel siswa secara purposive. Artinya sampel siswa diambil setelah didata tingkat motivasi siswa dalam tiap kelas sampel dengan menggunakan angket. Siswa yang memiliki tingkat homogenitas yang hampir sama digunakan sebagai sampel. Dari data siswa diambil 12 orang siswa yang dimasukkan dalam 4 kelompok, sehingga diperoleh jumlah keseluruhan sampel siswa adalah 48 orang. Tingkat homogenitas siswa ditentukan dari hasil pretest siswa,buku pegangan siswa, keikutsertaan dalam les belajar dan tingkat motivasi yang hampir sama.

\subsection{Variabel Penelitian.}

Adapun yang menjadi variabel penelitian ini adalah tingkat motivasi dan jenis bahan ajar sebagai variabel bebas. Sementara variabel terikatnya adalah hasil belajar siswa setelah diberi perlakuan pada pokok bahasan Hidrolisis Garam.

\subsection{Teknik Pengumpulan Data.}

Dalam penelitian ini, langkah - langkah yang dilakukan untuk mengumpulkan data adalah sebagai berikut :

1. Secara acak ditentukan empat kelompok dari delapan kelas paralel yang ada di sekolah tempat penelitian untuk dijadikan sebagai sampel kelas.

2. Sebelum pembelajaran dimulai, lebih dahulu dilakukan pendataan siswa di setiap kelas eksperimen yang telah terpilih menjadi sampel kelas. Pendataan dilakukan dengan kuisioner dan difokuskan untuk memperoleh data tingkat motivasi siswa sekaligus mengetahui faktor - faktor lain yang bisa mempengaruhi respon yang akan diamati, misalnya apakah siswa mengikuti privat/bimbingan belajar atau tidak, fasilitas yang dimiliki siswa, status ekonomi orangtua siswa.

3. Dilaksanakan pretest untuk mengukur prestasi belajar $\left(\mathrm{T}_{1}\right)$ sebelum perlakuan sekaligus menentukan sampel siswa ditinjau dari kehomogenan kemampuan awal.

4. Kemudian ditetapkan yang menjadi sampel siswa yaitu siswa yang relatif homogen statusnya. Jumlah siswa yang menjadi sampel di tiap kelas sampel harus sama. Dalam penelitian ini diambil 12 orang sampel siswa yang homogen statusnya.

5. Diberikan kombinasi perlakuan di setiap kelas eksperimen selama beberapa waktu tertentu sesuai yang telah ditetapkan dalam penelitian. Selama penelitian diusahakan agar kondisi kelompok tetap sama seperti lamanya waktu mengajarkecuali perbedaan bahan ajar. 
6. Setelah seluruh perlakuan selesai, dilakukan posttest untuk mengukur prestasi belajar $\left(\mathrm{T}_{2}\right)$

\subsection{Teknik Analisis Data.}

Setelah proses pembelajaran/pemberian perlakuan di setiap kelas eksperimen dan pelaksanaan post-tes telah selesai maka dilakukan prosedur analisis data [6] sebagai berikut :

1. Menghitung perubahan nilai hasil belajar siswa (selisih nilai hasil belajar sesudah dan sebelum perlakuan ) yang diperoleh di setiap kelas eksperimen, kemudian dimasukkan ke dalam tabel penyajian data sebagai berikut

Tabel 1. Data Peningkatan Nilai siswa SMA yang diberi Kombinasi Perlakuan Motivasi dan Bahan Ajar

\begin{tabular}{|c|c|c|}
\hline \multirow[t]{2}{*}{ Faktor Bahan Ajar (B) } & \multicolumn{2}{|c|}{ Faktor Motivasi (A) } \\
\hline & Motivasi Tinggi $\left(\mathrm{A}_{1}\right)$ & Motivasi Rendah $\left(\mathrm{A}_{2}\right)$ \\
\hline \multirow[t]{5}{*}{ Modul $\left(\mathrm{B}_{1}\right)$} & - & - \\
\hline & - & - \\
\hline & - & - \\
\hline & - & - \\
\hline & dst & dst \\
\hline \multirow[t]{6}{*}{ Buku Teks $\left(\mathrm{B}_{2}\right)$} & - & - \\
\hline & - & - \\
\hline & - & - \\
\hline & - & - \\
\hline & - & - \\
\hline & dst & dst \\
\hline
\end{tabular}

2. Melakukan uji persyaratan analisis statistik terutama uji normalitas dan uji homogenitas data.

Uji Normalitas. Uji normalitas diadakan untuk mengetahui normalitas data. Pengujian ini dilakukan dengan menggunakan uji Chi-kuadrat

Uji Homogenitas.Uji ini bertujuan untuk melakukan kegiatan pengujian mengenai kesamaan dua varians dengan rumus sebagai berikut :

$$
F F=\frac{\text { Varians Terbesar }}{\text { Varians Terkecil }} \quad \text { persamaan } 1 \text { [7] }
$$

Jika Fhitung $<$ Ftabel maka sampel berasal dari populasi yang homogen.

3. Melakukan uji hipotesis dengan Analisis of Varians (ANAVA) atau sidik ragam untuk menguji apakah ada pengaruh interaksi antara motivasi dan faktor bahan ajar terhadap hasil belajar siswa .Apabila ternyata ada pengaruh interaksi antara faktor motivasi dan faktor bahan ajar terhadap respon yang diamati (perubahan nilai hasil belajar siswa), maka dilanjutkan dengan melakukan Pengujian Pengaruh Sederhana Faktor Model pembelajaran untuk taraf B1 (modul) dan taraf B2 (buku teks) 


\section{Hasil dan Pembahasan}

\subsection{Hasil Penelitian}

Validitas Test dan Angket. Jumlah siswa (N) adalah 40 orang. Pada tingkat kepercayaan $(\alpha)=0,05$ maka akan diperoleh rtabel $=0,312$. Kriteria penilaian yaitu jika rxy $>$ rtabel maka item tersebut valid. Dari 30 soal yang diujikan diperoleh 22 soal yang valid dan 8 soal dinyatakan tidak valid. Dari 22 soal yang valid dipilih 20 soal yang digunakan sebagai instrument tes dalam penelitian Sebagaimana dalam penghitungan validitas test, dilakukan juga perhitungan validitas angket. Jumlah siswa $(\mathrm{N})$ adalah 40 orang. Pada tingkat kepercayaan $(\alpha)=0,05$ maka akan diperoleh rtabel $=0,312$. Kriteria penilaian yaitu jika rxy $>$ rtabel maka item tersebut valid. Dari 30 butir soal yang diberikan diperoleh 26 soal yang valid dan 4 soal dinyatakan tidak valid. Dari 26 soal yang valid dipilih 25 soal yang digunakan sebagai instrument tes dalam penelitian.

Reliabilitas Test dan Angket. Uji reliabilitas ditentukan dengan menggunakan rumus Kuder \& Richardson (KR20). Berdasarkan data uji reliabilitas tes dan perhitungan reliabilitas tes secara keseluruhan diperoleh reliabilitas tes (rhitung) sebesar 0,785. Setelah dibandingkan dengan rtabel=0,312, rhitung > rtabel, dengan demikian maka soalsoal dalam instrumen tes penelitian ini reliabel. Untuk menghitung realibilitas angket digunakan rumus Alpha Cronbach. Berdasarkan data uji realibilitas angket (rhitung) sebesar 0,819. Setelah dibandingkan dengan rtabel= 0,312, diperoleh bahwa rhitung> rtabel, dengan demikian maka soal-soal dalam instrumen tes penelitian ini reliabel

Hasil Analisis Data Penelitian. Sebelum dilakukan pengujian hipotesis maka terlebih dahulu disajikan peningkatan nilai hasil belajar kimia siswa.

Tabel 2. Data Peningkatan Nilai siswayang diberi Kombinasi Perlakuan Motivasi dan Bahan Ajar

\begin{tabular}{|c|c|c|}
\hline \multirow[t]{2}{*}{ Faktor Bahan Ajar (B) } & \multicolumn{2}{|c|}{ Faktor Motivasi (A) } \\
\hline & Motivasi Tinggi $\left(\mathrm{A}_{1}\right)$ & Motivasi Rendah $\left(\mathrm{A}_{2}\right)$ \\
\hline \multirow[t]{12}{*}{ Modul $\left(\mathbf{B}_{1}\right)$} & 25 & 25 \\
\hline & 45 & 30 \\
\hline & 55 & 35 \\
\hline & 50 & 35 \\
\hline & 60 & 40 \\
\hline & 55 & 40 \\
\hline & 45 & 40 \\
\hline & 40 & 25 \\
\hline & 40 & 15 \\
\hline & 30 & 40 \\
\hline & 35 & 30 \\
\hline & 45 & 45 \\
\hline \multirow[t]{9}{*}{ Buku Teks $\left(\mathbf{B}_{2}\right)$} & 35 & 55 \\
\hline & 40 & 60 \\
\hline & 50 & 35 \\
\hline & 60 & 50 \\
\hline & 50 & 45 \\
\hline & 50 & 45 \\
\hline & 55 & 45 \\
\hline & 40 & 40 \\
\hline & 45 & 20 \\
\hline
\end{tabular}




\begin{tabular}{lll}
\hline 20 & 40 \\
45 & 35 \\
30 & 35 \\
\hline
\end{tabular}

Setelah didapat data peningkatan hasil belajar siswa, kemudian dilakukan uji normalitas dan uji homogenitas.

Uji Normalitas. Uji ini dilakukan dengan menggunakan uji Chi Kuadrat dengan taraf signifikan $(\alpha)=0,05$. Kriteria pengujiannya adalah data terdistribusi normal jika harga X2< Chi Kuadrat tabel. Hasil uji normalitas untuk data awal siswa adalah terdistribusi normal. Berikut ini disajikan data normalitas data penelitian pada tabel:

Tabel 3. Data Hasil Perhitungan untuk Uji Normalitas

\begin{tabular}{ccccc}
\hline \multirow{2}{*}{ No. } & Kelompok & \multicolumn{3}{c}{ Posttest } \\
\cline { 3 - 5 } & & $\mathrm{X}^{2}$ hit & $\mathrm{X}^{2}$ tabel & Keterangan \\
\hline 1. & $\mathrm{~A}_{1} \mathrm{~B}_{1}$ & 4,30 & 11,07 & Normal \\
2. & $\mathrm{~A}_{1} \mathrm{~B}_{2}$ & 9,39 & 11,07 & Normal \\
3. & $\mathrm{~A}_{2} \mathrm{~B}_{1}$ & 6,78 & 11,07 & Normal \\
4. & $\mathrm{~A}_{2} \mathrm{~B}_{2}$ & 6,17 & 11,07 & Normal \\
\hline
\end{tabular}

Uji Homogenitas. Dari uji homogenitas didapat bahwa semua data homogen. Karena $F(0,05)(11,11)=2,82$. Fhit < Ftabel

Tabel 4. Data Homogenitas Siswa

\begin{tabular}{cccccc}
\hline No & Kelompok & $\mathrm{S}^{2}$ & $\mathrm{~F}_{\text {hit }}$ & $\mathrm{F}_{\text {tabel }}$ & Keterangan \\
\hline 1. & $\mathrm{~A}_{1} \mathrm{~B}_{1}$ & 108,33 & & & Homogen \\
2. & $\mathrm{~A}_{1} \mathrm{~B}_{2}$ & 65,91 & 1,64 & 2,82 & \\
3. & $\mathrm{~A}_{2} \mathrm{~B}_{1}$ & 108,33 & & & \\
4. & $\mathrm{~A}_{2} \mathrm{~B}_{2}$ & 111,17 & & & \\
\hline
\end{tabular}

Uji Hipotesis. Dari hasil posttest diperoleh rataan nilai seperti dalam table dibawah ini.

Tabel 5. Rataan Nilai Hasil Belajar Siswa untuk setiap kombinasi perlakuan

\begin{tabular}{ccc}
\hline \multirow{2}{*}{ Faktor Bahan Ajar (B) } & \multicolumn{2}{c}{ Faktor Motivasi (A) } \\
\cline { 2 - 3 } & $\mathrm{A}_{1}$ & $\mathrm{~A}_{2}$ \\
\hline $\mathrm{B}_{1}$ & $44,17 \pm 10,41$ & $40,83 \pm 10,41$ \\
\hline $\mathrm{B}_{2}$ & $32,50 \pm 8,12$ & $42,08 \pm 10,54$ \\
\hline
\end{tabular}

Uji hipotesis dilakukan dengan menggunakan analisa ragam faktorial 2 x 2. Data yang diperoleh dari hasil belajar siswa disusun berdasarkan jenis bahan ajar siswa. Rataan nilai hasil belajar siswa yang menggunakan bahan ajar modul dengan motivasi tinggi $(44,17 \pm 10,41)$ tidak berbeda nyata dengan rataan nilai hasil belajar siswa yang menggunakan bahan ajar modul dengan motivasi rendah $(40,83 \pm 10,41)$. Sedangkan rataan nilai hasil belajar siswa yang menggunakan bahan ajar buku paket dengan motivasi tinggi $(32,50 \pm 8,12)$ berbeda nyata dengan rataan nilai hasil belajar siswa yang menggunakan bahan ajar modul dengan motivasi rendah $(42,08 \pm 10,54)$.

Tabel 6. Daftar analisis ragam nilai hasil belajar siswa

\begin{tabular}{cccccc}
\hline Sumber Keragaman & $\mathrm{db}$ & $\mathrm{JK}$ & $\mathrm{KT}$ & $\mathrm{F}_{\text {hit }}$ & $\mathrm{F}_{(0,05, \mathrm{db})}$ \\
\hline Perlakuan & 3 & 943,2292 & - & - & - \\
\hline
\end{tabular}




\begin{tabular}{cccccc}
\hline Faktor A & 1 & 117,1875 & 117,1875 & 1,1905 & 4,06 \\
\hline Faktor B & 1 & 325,5208 & 325,5208 & 3,3069 & 4,06 \\
\hline Interaksi AB & 1 & 500,5209 & 500,5209 & 5,0847 & 4,06 \\
\hline Galat & 44 & 4331,25 & 98,4375 & - & - \\
\hline Total & 48 & 5274,4792 & - & - & - \\
\hline
\end{tabular}

Dari tabel analisis ragam dapat dilihat bahwa Fhit $(\mathrm{AB})>\mathrm{F}(0,05)(1,44)$ atau 5,08 $>$ 4,06 maka Ho ditolak artinya ada pengaruh interaksi antara motivasi dan bahan ajar terhadap nilai hasil belajar kimia siswa. Karena terdapat pengaruh, maka dilakukan pengujian pengaruh sederhana faktor motivasi untuk taraf $\mathrm{B}_{1}$ (bahan ajar modul) menunjukkkan Fhit > Ftabel maka Ho ditolak. Karena Fhit > Ftabel maka Ho ditolak artinya terdapat perbedaan yang sangat signifikan dari rataan nilai hasil belajar kimia siswa dengan motivasi yang berbeda yang diajar dengan berbagai jenis bahan ajar.

\subsection{Pembahasan}

Pada awal hendak melaksanakan penelitian, peneliti terlebih dahulu memberikan pretes untuk melihat pengetahuan awal siswa mengenai materi pokok hidrolisis garam. Dari hasil pretes tersebut diketahui bahwa nilai rata-rata siswa tersebut tidak berbeda dan masih tergolong sangat rendah. Hal tersebut dapat dimaklumi, karena siswa pada kedua kelas penelitian belum menerima pembelajaran mengenai materi pokok hidrolisis garam dan hasil tersebut juga memberikan gambaran bahwa rata-rata tingkat pengetahuan awal siswa dari kedua kelas penelitian cenderung sama. Selain itu juga dilakukan pendataan tentang tingkat motivasi siswa terhadap pelajaran kimia. Pendataan ini dilakukan dengan menggunakan angket. Kemudian siswa diajar dengan menggunakan jenis bahan ajar modul dan buku paket. Setelah dilakukan pengajaran maka siswa diberi posttest untuk mengetahui hasil belajar siswa. Data hasil belajar yang diperoleh diolah dengan menggunakan analisis varians 2 × 2 sebagai uj hipotesis.Perhitungan interaksi antara motivasi dan bahan ajar menunjukkan adanya interaksi antara motivasi belajar siswa dengan jenis bahan ajar terhadap rataan nilai hasil belajar kimia siswa atau Fhit $(\mathrm{AB})>\mathrm{F}(0,05)(1,44)$ atau 5,08 > 4,06 maka Ho ditolak. Karena adanya interaksi maka harus dilakukan uji lanjutan untuk mengetahui sejauh mana ketergantungan antara factor motivasi dengan jenis bahan ajar yaitu dengan uji pengaruh sederhana. Pengujian sederhana dari factor motivasi untuk taraf $\mathrm{B}_{1}$ ( bahan ajar modul) didapat hasil bahwa Fhit $=0,62$ sedangkan Ftabel pada taraf $5 \%=4,30$. Karena Fhit $<$ Ftabel pada taraf 5\% maka Ho diterima berarti tidak ada perbedaan yang signifikan rataan nilai hasil belajar siswa yang diajar dengan modul dengan tingkat motivasi yang berbeda. Selanjutnya dilakukan uji BNT, pada uji ini diperoleh hasil bahwa $\mathrm{BNT}_{(0,05)}=9,35$ dan $\left|\bar{Y}_{1}-\bar{Y}_{2}\right|=3,33$. Karena $\left|\bar{Y}_{1}-\bar{Y}_{2}\right|$ lebih kecil dari $\mathrm{BNT}_{(0,05)}$ maka dapat disimpulkan bahwa rataan nilai hasil belajar kimia siswa yang menggunakan bahan ajar modul dengan motivasi tinggi $(44,17 \pm$ 10,41) tidak berbeda nyata dengan hasil belajar siswa yang menggunakan bahan ajar modul dengan motivasi rendah $(40,83 \pm 10,41)$.

Pada pengujian sederhana factor motivasi untu taraf $\mathrm{B}_{2}$ (bahan ajar buku paket) didapat hasil bahwa Fhit $=6,22$ sedangkan Ftabel pada taraf $5 \%=4,30$. Karena Fhit > Ftabel pada taraf 5\% maka Ho ditolak berarti ada perbedaan yang signifikan rataan nilai hasil belajar siswa yang diajar dengan buku paket dengan tingkat motivasi yang berbeda. Selanjutnya dilakukan uji BNT, pada uji ini diperoleh hasil bahwa $\mathrm{BNT}_{(0,05)}=8,45$ dan $\left|\overline{Y_{1}}-\overline{Y_{2}}\right|=9,59$. Karena $\left|\bar{Y}_{1}-\bar{Y}_{2}\right|$ besar dari $\mathrm{BNT}_{(0,05)}$ maka dapat disimpulkan bahwa rataan nilai hasil belajar kimia siswa yang menggunakan bahan ajar buku paket dengan motivasi tinggi $(32,50 \pm 8,12)$ berbeda nyata dengan hasil belajar siswa yang menggunakan bahan ajar buku paket dengan motivasi rendah $(42,08 \pm 10,54)$.

Berdasarkan hasil pembahasan diperoleh bahwa terdapat perbedaan nilai hasil belajar siswa yang diajar dengan bahan ajar modul dan buku paket yag dikombinasikan dengan tingkat motivasi tinggi dan motivasi rendah. Diperoleh bahwa siswa yang motivasi tinggi cenderung lebih sesuai menggunakan bahan ajar buku paket terlihat dari rataannya yang lebih tinggi. Siswa yag motivasi rendah cenderung lebih sesuai diajar dengan menggunakan modul. 


\section{Kesimpulan}

Dari analisis data maka dapat disimpulkan:

1. Tidak ada pengaruh motivasi terhadap hasil belajar kimia siswa

2. Tidak ada pengaruh jenis bahan ajar terhadap hasil belajar kimia siswa.

3. Ada interaksi antara motivasi dan jenis bahan ajar terhadap hasil belajar kimia siswa.

4. Tidak ada perbedaan rataan nilai hasil belajar kimia siswa yang diajar dengan menggunakan modul dengan tingkat motivasi yang berbeda

5. Terdapat perbedaan rataan nilai hasil belajar kimia siswa yang diajar dengan menggunakan buku paket dengan tingkat motivasi yang berbeda.

6. Pengajaran dengan mengunakan modul pada siswa yang memiliki motivasi tinggi $(44,17 \pm 10,41)$ memberikan rataan nilai hasil belajar lebih rendah dibandingkan dengan rataan nilai hasi belajar siswa yang memiliki motivasi rendah $(40,83 \pm 10,41)$.

7. Pengajaran dengan menggunakan buku paket pada siswa yang memiliki motivasi tinggi $(32,50 \pm 8,12)$ memberikan rataan nilai hasil belajar lebih tinggi disbandingkan dengan rataan nilai hasil belajar siswa yang memiliki motivasi rendah $(42,08 \pm 10,54)$.

\section{Referensi}

[1] Sabri, Ahmad., (2010), Strategi Belajar Mengajar dan Micro Teaching, PT Ciputat Press, Ciputat.

[2] Manik, Sahat, (2008), Hubungan Bahan Ajar dengan Prestasi Belajar Akuntansi Siswa SMA HKBP SIDORAME MEDAN T.A 2007/2008, FE UNIMED, Medan.

[3] Pasaribu, Roni, (2007), Pengaruh Jenis Bahan Ajar Terhadap Hasil Belajar Geografi Siswa di SMA, FIS UNIMED, Medan.

[4] Sinaga, Surung, (2009), Hubungan Bahan Ajar Dengan Prestasi Belajar Matematika Siswa Dalam Pokok Bahasan Dimensi Tiga Di SMA Negeri 1 Sunggal, FMIPA UNIMED, Medan.

[5] Setyowati., (2007),Pengaruh Motivasi Belajar Terhadap Hasil Belajar Siswa KelasVII SMPN 13 Semarang, Skripsi FE Universitas Negeri Semarang, Semarang.

[6] Silitonga, P.M., (2011), Metode Penelitian Pendidikan, FMIPA Universitas Negeri Medan, Medan.

[7] Silitonga, P.M., (2011), Statistik Teori dan Aplikasi dalam Penelitian, FMIPA Universitas Negeri Medan, Medan. 